\title{
onkopedia
}

onkopedia guidelines

\section{Paroxysmal Nocturnal Hemoglobinuria (PNH)}

\section{Guideline}

Recommendations from the society for diagnosis and therapy of haematological and oncological diseases 


\section{Publisher}

DGHO Deutsche Gesellschaft für Hämatologie und Medizinische Onkologie e.V.

Alexanderplatz 1

D-10178 Berlin

Executive chairman: Prof. Dr. med. Carsten Bokemeyer

Phone: $+49(0) 3027876089$ - 0

Fax: +49(0)3027876089- 18

info@dgho.de

www.dgho.de

\section{Contact person}

Prof. Dr. med. Bernhard Wörmann

Medical superintendent

\section{Source}

www.onkopedia-guidelines.info

The information of the DGHO Onkopedia Web Site is not intended or implied to be a substitute for professional medical advice or medical care. The advice of a medical professional should always be sought prior to commencing any form of medical treatment. To this end, all component information contained within the web site is done so for solely educational purposes. DGHO Deutsche Gesellschaft für Hämatologie und Onkologie and all of its staff, agents and members disclaim any and all warranties and representations with regards to the information contained on the DGHO Web Site. This includes any implied warranties and conditions that may be derived from the aforementioned web site information. 


\section{Table of contents}

1 Definition and Basic Information.................................................. 2

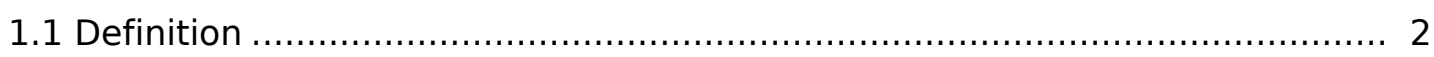

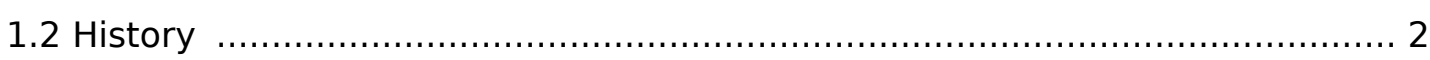

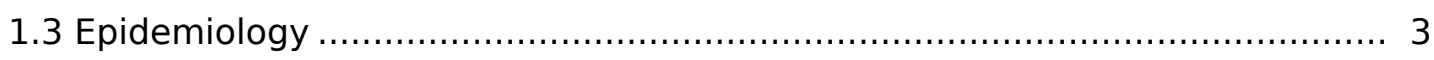

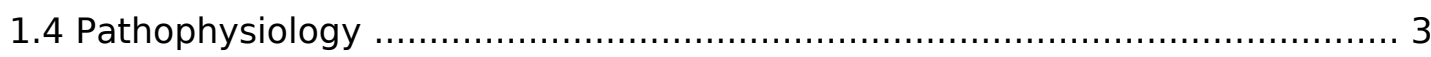

2 Clinical Presentation .............................................................. 3

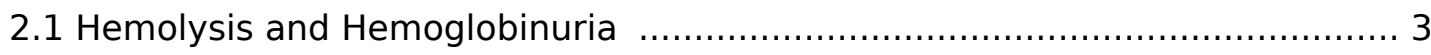

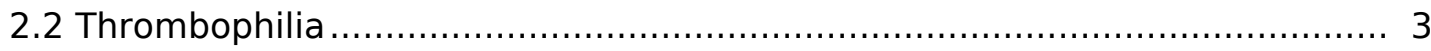

2.3 Secondary Aplastic Syndrome or AA-PNH-Syndrome ............................ 4

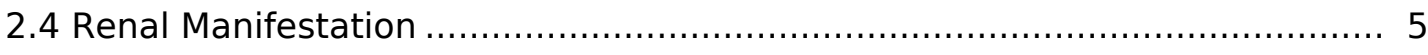

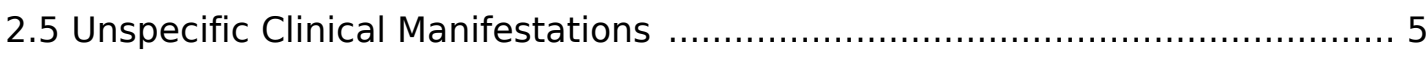

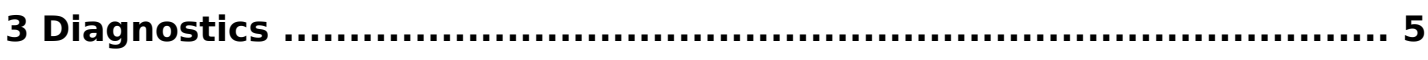

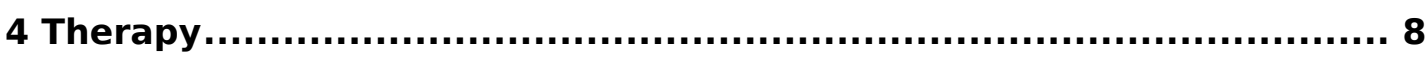

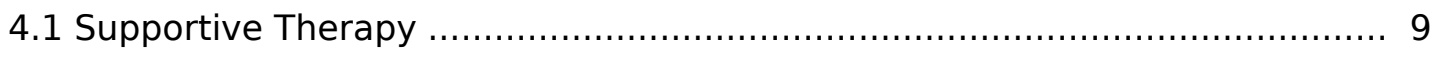

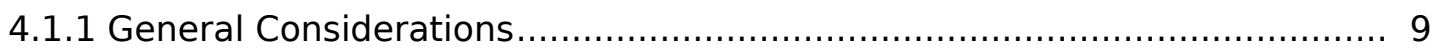

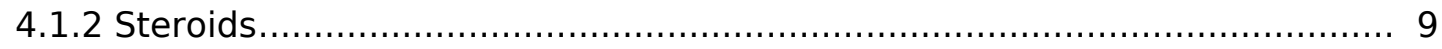

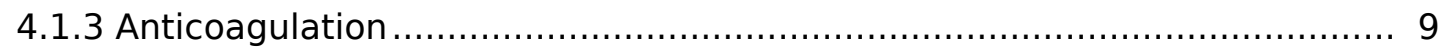

4.1.4 Immunosuppressive Therapy ............................................... 10

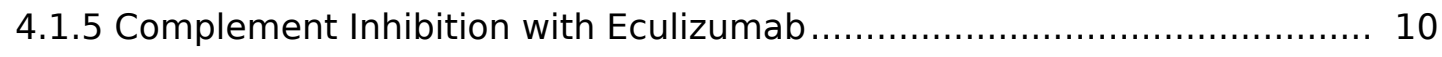

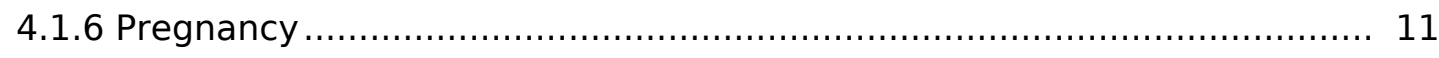

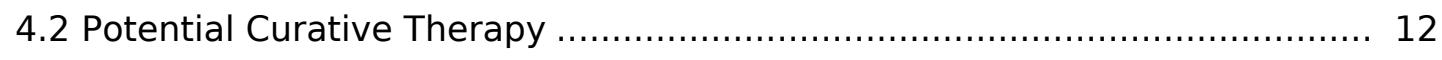

4.2.1 Allogeneic Stem-Cell Transplantation ....................................... 12

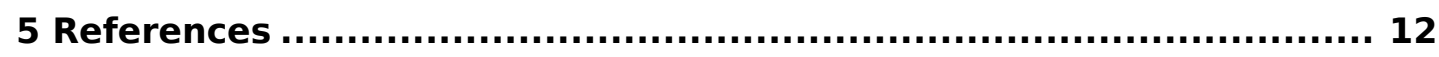

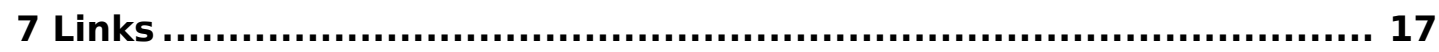

8 Authors' Affiliations ........................................................... 17

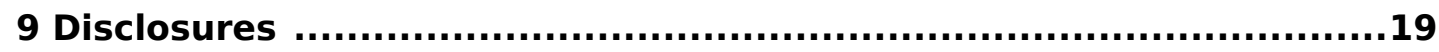




\section{Paroxysmal Nocturnal Hemoglobinuria (PNH)}

Status: March 2012

Authors: Jörg Schubert, Peter Bettelheim, Tim Henrik Brümmendorf, Alexander Röth, Hubert Schrezenmeier, Georg Stüssi

\section{Definition and Basic Information}

Paroxysmal nocturnal hemoglobinuria (PNH) is an acquired corpuscular hemolytic anemia which because of its highly variable clinical symptoms often makes diagnosis and prediction of its clinical course difficult. PNH is a clonal hematopoietic disorder, in which one or several pluripotent stem cells acquire the characteristic defect of glycosyl phosphatidylinositol (GPI)-anchored surface molecules and proliferate in the bone morrow. The development of eculizumab, a targeted inhibitor of the terminal complement cascade, has distinctly improved the clinical symptoms of $\mathrm{PNH}$ patients and gives us the option to treat disease-associated complications.

\subsection{Definition}

Paroxysmal nocturnal hemoglobinuria (PNH) is a rare acquired disease affecting the hematopoietic stem cells in the bone marrow. The clinical progression of the disease is extremely variable. Characteristics are intravascular hemolysis, thrombophilia with a propensity to thrombosis in typical and atypical locations, and cytopenia which in its manifestation may range from mild subclinical cytopenia to severe pancytopenia.

\subsection{History}

1882 Initial description by Strübing of a 29-year-old patient who sought treatment because of fatigue, abdominal pain and intravascular hemolysis, occurring particularly after physical exertion and excessive alcohol consumption [1]

1911 Marchiafava and Micheli reported hemolytic anemia associated with hemoglobinuria

1937 Introduction of the acid hemolysis test by Ham [2]

1954 Evidence of the central role of the complement system in the pathophysiology of PNH [3]

1985 Evidence of deficient complement-regulating surface molecules in PNH [4]

1992 Evidence of defective biosynthesis resulting in the absence of GPI-anchored proteins on the surface of GPI-deficient cells [5]

1993 Discovery of a somatic mutation in the PIG-A-gene of blood cells in patients with $\mathrm{PNH}[6]$ 


\subsection{Epidemiology}

$\mathrm{PNH}$ is a very rare disease with a prevalence (regarding the evidence of a significant GPI- (PNH) clone) of approx. 16 cases/1 million inhabitants, and an incidence rate of approx. 1.3 cases/1 million inhabitants (data from Great Britain/France). No reliable epidemiological data are available for the prevalence and incidence of PNH in Germany. Considering the clinical heterogeneity it must be assumed that the disease is distinctly "underdiagnosed" [7].

\subsection{Pathophysiology}

The cause of paroxysmal nocturnal hemoglobinuria is an acquired somatic mutation of the PIG-A-gene in either one or several pluripotent hematopoietic stem cells of the bone marrow [8,9]. Not all stem cells of the bone marrow are affected, hence a so-called mosaic situation exists. Additional pathophysiological mechanisms may include an autoimmunity-mediated depletion of GPI+-, i.e. healthy stem cells leading to secondary accumulation of GPI-deficient PNH stem cells, and the existence of an intrinsic growth advantage by the GPI deficient stem cells [10]. The predominant consequence of GPI deficiency on peripheral blood cells is the absence of so-called complement-inactivating proteins, especially from the surface of erythrocytes. In this regard, particular mention must be made of CD55, the so-called "decay-accelerating factor (DAF)" and/or CD59, the "membrane inhibitor of reactive lysis (MIRL)" [11]. Once complement is activated the red blood cells become vulnerable to terminal complement-mediated lysis due to the constitutive absence of transmembrane molecules. As almost all PNHspecific symptoms are also described in a case with isolated CD59 defect, the CD59 molecule is of crucial importance to $\mathrm{PNH}$ pathogenesis [12].

\section{Clinical Presentation}

\subsection{Hemolysis and Hemoglobinuria}

Although the dark-brown morning urine belongs to the classic manifestation of $\mathrm{PNH}$, this typical clinical sign can only be seen in about $26 \%$ of all PNH patients at the time of initial diagnosis. Many PNH patients do not have no clinically obvious hemoglobinuria or, at most, intermittent episodes which are not associated with the circadian rhythm. However, there is a connection between the occurrence of hemoglobinuria and the size of the PNH clone, i.e. the proportion of GPI-deficient cells in the peripheral blood. Physical weakness, fatigue, and stress dyspnea are the characteristic clinical symptoms of chronic hemolytic anemia. The intensity of fatigue is not strictly correlated with the severity of the anemia, however, a correlation does exist with the size of the $\mathrm{PNH}$ clone.

\subsection{Thrombophilia}

Thromboembolic complications are the most relevant clinical complications in patients with $\mathrm{PNH}$ and represent the main cause of the increased morbidity and 
mortality of this disease [13]. About 40 to $60 \%$ of all patients with PNH develop thromboses, which predominately affect the venous system. The probability to acquire thrombosis correlates with the size of the PNH clone, which can be measured in granulocytes, and the existence of classic symptoms, i.e. hemolysis and hemoglobinuria. Venous thromboses in PNH patients appear in typical and atypical locations such as the abdominal, particularly the hepatic or in the cerebral veins.

1. The Budd Chiari-Syndrome (BCS) is a typical manifestation of thrombosis in PNH patients $[14,15]$. Clinical symptoms of hepatic vein thrombosis are abdominal pain, hepatomegaly, jaundice, ascites formation, and weight gain. The thrombosis might affect both the small and the large hepatic veins. The course and prognosis of BCS in PNH patients does not differ significantly from that of patients with BCS of other origin [16].

2. In addition to hepatic vein thromboses $\mathrm{PNH}$ patients also display an increased rate of portal vein thromboses, which occur at a distinctly lower rate than BCS [17]. In this case nausea, vomiting, abdominal pain, and hepatic dysfunction are the major clinical symptoms.

3. Another highly sensitive anatomic region for the appearance of venous thromboses in PNH patients are the cerebral veins, in particular the sagittal cerebral veins and sinuses. Clinical characteristics are headaches, which are occasionally associated with focal neurological deficits.

4. Apart from the typical and atypical venous manifestations of thromboembolic events, arterial thromboembolism also occurs and results in the occlusion of cerebral, coronary, visceral, and retinal vessels, leading to the characteristic symptoms. The frequency of these arterial occlusions was reported as high as 39 percent of all thromboembolic events in a Korean cohort [18]. However, according to observations made in other cohorts worldwide, this appears to be relatively high. Still, PNH should be considered also in case of arterial events, particularly in patients without preexisting angiopathy.

\subsection{Secondary Aplastic Syndrome or AA-PNH-Syndrome}

There is a close clinical and pathophysiological connection between aplastic anemia and $\mathrm{PNH}$ :

1. The risk for developing a clinical PNH is at approx. $15-25 \%$ for patients with an acquired aplastic anemia.

2. At initial diagnosis $>20 \%$ of patients with aplastic anemia display a small or moderate GPI-deficient population in the bone marrow [21].

3. Depending on the study, $10-20 \%$ of patients with aplastic anemia develop myelodysplasia in the course of their disease, often many years after termination of immunosuppressive therapy [22].

4. An aberrant cytogenetic findings prevails in approx. $20 \%$ of $\mathrm{PNH}$ patients already at initial diagnosis [23]. 
5. Allogenic stem-cell transplantation can prevent the secondary transformation of aplastic anemia in to $\mathrm{PNH}$.

Hence it follows that secondary clonal diseases, e.g. PNH and MDS, characterize the natural course of aplastic anemia.

\subsection{Renal Manifestation}

Functional renal disorders are observed in two-thirds of all patients with $\mathrm{PNH}$, in $21 \%$ even in advanced stage of renal failure [24]. Pathophysiology includes hemosiderin deposits in the proximal tubules as well as microvascular thromboses. Clinically dominant is an impaired tubular function and a gradually declining creatine clearance in the majority of patients [25].

\subsection{Unspecific Clinical Manifestations}

The distinctly pronounced fatigue is often the clinical symptom which is most obvious in PNH patients. Typically, this fatigue does not correlate to the severity of anemia but to the severity of hemolysis. In addition, intermittent esophageal spasms, chest pain, nausea and swallowing disorders appear, the latter especially in conjunction with hemolytic episodes. Male patients occasionally report of erectile dysfunction. In addition, moderate to sometimes intensive pain, in particular back pain, headaches, muscle pain and abdominal pain appears in association with hemolytic crises. As applies to the increased incidence of pulmonary-arterial hypertension, the pain is probably causally related to nitrogen oxide (NO) catabolism which is enhanced by intravascular hemolysis and results in the deregulation of endothelial and smooth muscle cells in the vascular wall and hence in a condition of vasculopathy. It can be influenced by treatment with the $\mathrm{C} 5$ antibody eculizumab (see below) [26].

\section{Diagnostics}

Diagnostics in case of suspected PNH should include the following steps [27]:

- Comprehensive family and medical history in order to distinguish whether an acquired disorder or congenital differential diagnoses (e.g. membranopathies, enzymopathies) are more likely.

- Medical history including targeted questioning about PNH-typical symptoms (symptoms of anemia, fatigue, dyspnea, urine discoloration, recurrent abdominal pain crises, dysphagia, headaches, erectile dysfunction, thromboembolic events, signs of hemorrhages, frequent infections).

- Physical examination (particular attention should be given to the following aspects: signs of anemia, jaundice, signs of acute or previous thromboses, signs of hemorrhages, obvious constitutional features as occur in congenital aplastic anemias (see elsewhere), splenomegaly).

- Sonography (upper abdomen, including color Doppler) paying special attention to the following aspects: dimensions of the liver and spleen; Doppler 
sonographic signs of acute or previous thromboses of the hepatic vein, portal vein, splenic vein, or mesenterial vein). If an acute thrombotic event is suspected, color Doppler and angiography of other regions (e.g. cerebral veins) is recommended, if feasible.

- Laboratory analyses [27- 29]

- Complete blood cell count, including leukocyte count with differential, reticulocytes

- Erythrocyte morphology (particularly important to exclude the existence of fragmentocytes when distinguishing PNH from microangiopathic hemolysis).

- Hemolytic parameters. Mandatory: LDH, total bilirubin, direct bilirubin; haptoglobin, hemopexin, urine status including hemoglobin analysis. Optional: free hemoglobin in the serum; hemosiderin in the urine.

- Direct antiglobulin test (DAT); blood group.

- Flow-cytometric analysis of GPI-anchored proteins (see Table 1)

- Bone-marrow diagnostics including cytology, cytogenetics and histology, in patients with significant cytopenia of such an extent that PNH is suspected in the context of another hematological disease (esp. aplastic anemia; MDS).

If significant GPI-deficient populations are diagnosed in the flow cytometric analysis, the analytical profile should be extended by the following parameters:

- Creatinine, creatinine clearance.

- Ferritin, iron, transferrin, transferrin saturation, reticulocyte hemoglobin, soluble transferrin receptor.

In case of ferritin values $>1.000 \mathrm{ng} / \mathrm{ml}$ further clarification of potential organ damage due to an iron overload (echocardiography, blood glucose/diurnal bloodglucose profile; thyroid parameters, TSH; if possible, FerriScan).

- Plasma concentrations of folic acid and vitamin $B_{12}$

- In young patients with an indication for stem cell transplantation: HLA typing of the patient and siblings.

- If there is a positive family case history for thromboembolic events: Thrombophilia-screening (Factor $\mathrm{V}$ Leiden; prothrombin mutations; Protein $\mathrm{C}$, Protein S etc.).

- Genetic analyses (PIG-A gene) to confirm the diagnosis will generally will not be necessary if the constellation of findings is typical. Genetic diagnostics might be reasonable in case of atypical clinical manifestations/atypical flow-cytometric results [30-32].

The standard method to determine a PNH-typical GPI-anchor defect consists in the analysis of multiparameter flow cytometry (at least granulocytes and red blood cells) [29, 33]. Indications are summarized in Table 1. 
Table 1: Indications for Flow-Cytometric Diagnostics GPI-Anchored Proteins [27- 29]

- Acquired, Coombs-negative hemolytic anemia (without signs of a microangiopathic hemolytic anemia)

- Intravascular hemolysis (haptoglobin not measurable, hemoglobinuria, elevated free plasma hemoglobin)

- Thromboses, if at least one of the criteria below is fulfilled:

"Atypical" locations (sinus vein thrombosis, Budd-Chiari syndrome, mesenterial vein or portal vein or splenic vein thrombosis, dermal thromboses)

- Thromboses (irrespective of their location) in patients showing signs of hemolytic anemia

- Thromboses (irrespective of their location) in conjunction with cytopenia

- Thromboses (irrespective of their location, including arterial thromboses) without risk factors

- Patients with an unclear iron deficiency anemia (after meticulous exclusion of other causes) in association with signs of hemolytic anemia

- Diagnosis or strong suspicion of aplastic anemia

- Diagnosis or strong suspicion of myelodysplastic syndrome

- Recurrent abdominal pain crises of uncertain etiology or dysphagia, particularly if concomitant signs of hemolysis exist

Recommendations for disease monitoring by flow cytometry are summarized in Table 2.

Table 2: Frequency of Flow-Cytometric PNH Analyses [27, 28]

\begin{tabular}{|c|c|}
\hline Indication & Diagnostics \\
\hline In case of suspected hemolytic PNH & Initial diagnostics according to Table 1 \\
\hline $\begin{array}{l}\text { In case of evidence of a significant GPI- } \\
\text { deficient cell population }\end{array}$ & $\begin{array}{l}\text { Flow cytometric analyses in intervals of six months during the first two } \\
\text { years after diagnosis; thereafter annually if the course of the disease } \\
\text { is stable. }\end{array}$ \\
\hline $\begin{array}{l}\text { In case of fluctuating proportion of GPI- } \\
\text { deficient cells or distinct alteration of } \\
\text { the clinical symptoms }\end{array}$ & Individual adjustment of the intervals of analysis. \\
\hline Under eculizumab therapy & $\begin{array}{l}\text { Repetition in annual intervals and/or if clinical symptoms are altered } \\
\text { or in case of treatment changes. }\end{array}$ \\
\hline $\begin{array}{l}\text { After allogenic stem-cell transplanta- } \\
\text { tion due to PNH }\end{array}$ & $\begin{array}{l}\text { Test every three months in case chimerism analysis reveals a positive } \\
\text { recipient percentage, until the GPI-deficient population is no longer } \\
\text { measurable, thereafter annual remission controls. Tests are to pro- } \\
\text { ceed within the interval if a relapse is suspected for clinical reasons. }\end{array}$ \\
\hline In case of aplastic anemia & $\begin{array}{l}\text { At diagnosis, thereafter every } 12 \text { months should there be no signs of } \\
\text { hemolysis. }\end{array}$ \\
\hline
\end{tabular}

Several relevant aspects, especially also including pre-analytics, are shown in Table 3.

Table 3: Flow-Cytometric Analysis of GPI-Anchored Proteins [25, 33-35]

\begin{tabular}{|l|l|}
\hline \multicolumn{1}{|c|}{ Criterion } & \multicolumn{1}{c|}{ Comments } \\
\hline Material & $\begin{array}{l}\text { Peripheral blood (preferentially EDTA anticoagulated). } \\
\text { (No analysis of the bone marrow in the scope of routine diagnostics (!), as the physiological } \\
\text { changes in the expression of GPI-anchored proteins in the context of hematopoietic differenti- } \\
\text { ation makes the interpretation very difficult). }\end{array}$ \\
\hline
\end{tabular}




\begin{tabular}{|l|l|}
\hline $\begin{array}{l}\text { Interval } \\
\text { between sam- } \\
\text { pling and analy- } \\
\text { sis }\end{array}$ & $\begin{array}{l}\text { If possible }<48 \text { hours, } 72 \text { hours at maximum } \\
\text { If transport times }>24 \text { hours the sample should be chilled }\left(+1 \text { to }+10^{\circ} \mathrm{C}\right) .\end{array}$ \\
\hline Cell lineages & $\begin{array}{l}\text { At least granulocytes and erythrocytes; } \\
\text { Analysis of the reticulocytes can provide relevant additional information. Analysis of lympho- } \\
\text { cytes and platelets is optional. } \\
\text { At least two different makers per cell line should be analyzed (GPI-anchored proteins or the } \\
\text { GPI-anchors themselves). The examined cell population should be identified with a non-GPI- } \\
\text { anchored marker. }\end{array}$ \\
\hline $\begin{array}{l}\text { Reporting of } \\
\text { Results }\end{array}$ & $\begin{array}{l}\text { Reports should contain quantitative statements relating to the analyzed cell lines, including a } \\
\text { separate report of the percentage of cells with a completely absent expression of GPI- } \\
\text { anchored proteins (PNH type-III cells) and reduced expression (PNH type-II cells). }\end{array}$ \\
\hline Sensitivity & $\begin{array}{l}\text { Routine analyses should enable the identification of a GPI-deficient population exceeding a } \\
\text { relative proportion of } 1 \% .\end{array}$ \\
\hline
\end{tabular}

For methodical aspects concerning test performance we refer to the specialized literature [33-35]. The participation in interlaboratory ring trials on flow-cytometric diagnostics which have been organized in Germany since 2011 is also recommended.

\section{Therapy}

A therapy algorithm is shown in Figure 1.

\section{Figure 1: Algorithm for the Therapy of Patients with Paroxysmal Nocturnal} Hemoglobinuria

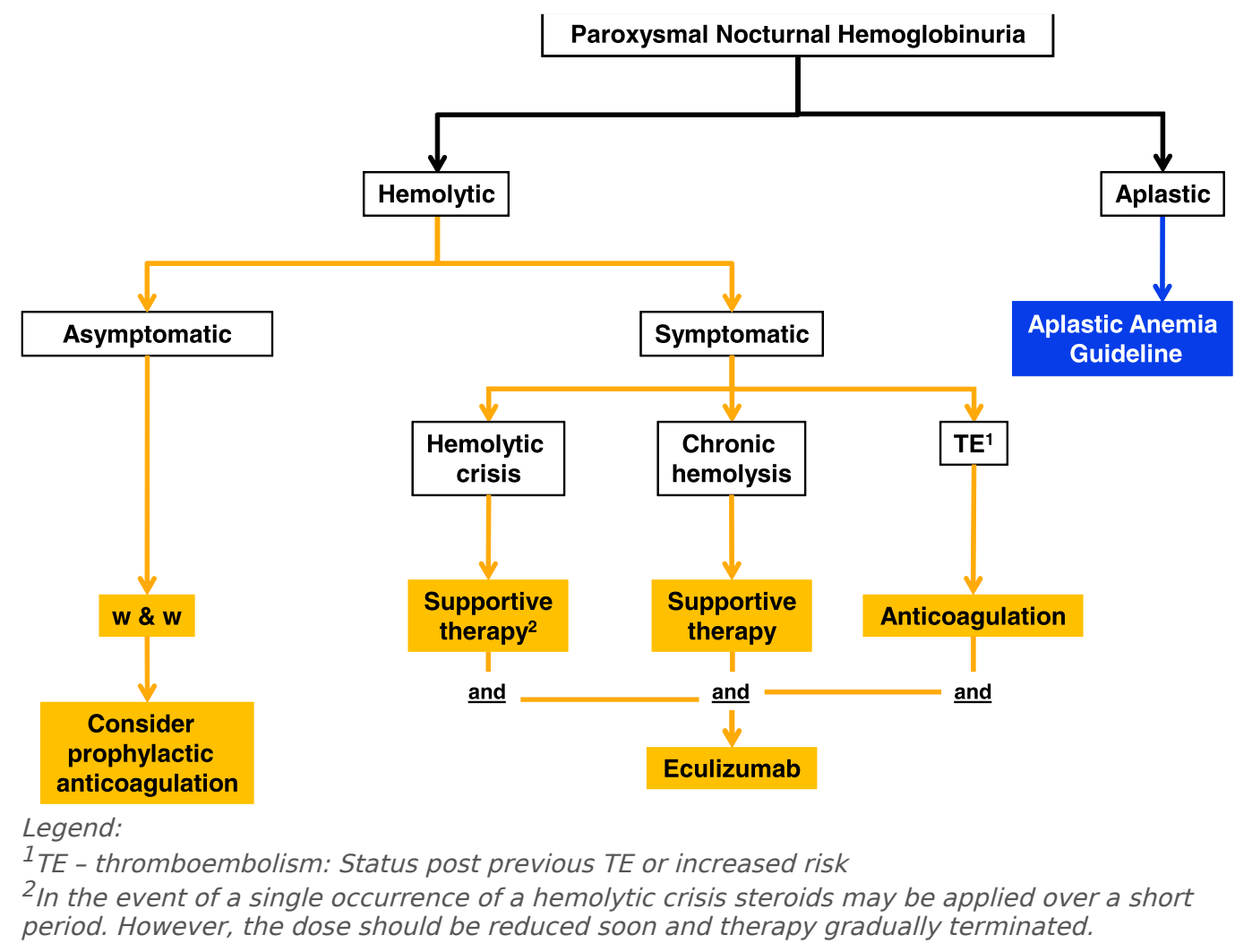




\subsection{Supportive Therapy}

\subsubsection{General Considerations}

The following recommendations essentially relate to the therapy of hemolytic $\mathrm{PNH}$. As far as the therapy of AA with a PNH clone is concerned, we refer to the Onkopedia Guideline Aplastic Anemia.

- Substitution with erythrocyte transfusions (washed erythrocyte transfusions are not necessary) [36].

- Administration of folic acid (1-5 mg/d, PO) and, if necessary, vitamin $\mathrm{B}_{12}$ as well (in case of deficiency) due to the considerably enhanced compensatory erthyropoiesis in the bone marrow.

- Oral iron substitution in case of a deficiency, under control of iron storage parameters (ferritin, transferrin saturation, reticulocyte hemoglobin). Intravenous administration of iron should be avoided as it might trigger a hemolytic seizure. Under therapy with eculizumab the chronic iron deficiency due to hemoglobinuria and/or hemosiderinuria is stopped through an effective inhibition of intravascular hemolysis. Hence no uncontrolled administration of iron should proceed under therapy with eculizumab. In case of a potential iron overload [37] (particularly in case of a residual transfusion demand) an iron depletion should be initiated, if possible.

- Bacterial infections should be treated with antibiotics early, as they might cause an exacerbation of PNH accompanied with hemolytic crises [28].

- Sufficient hydration during hemolytic crises.

\subsubsection{Steroids}

- Empirical therapy, without randomized studies [38-40].

- Short-term pulse therapy with steroids (e.g. 1-2 mg prednisone/kg b.w. over several days) might under certain circumstances exert a beneficial influence on severity and duration of the hemolytic crises.

- Permanent therapy with steroids is not recommended [28]

\subsubsection{Anticoagulation}

- Life-long secondary prophylactic anticoagulation after a thromboembolic event. Despite effective anticoagulation there still remains a relapse risk for thromboembolic events, which under certain circumstances may be an indication for therapy with eculizumab [41].

- Therapy of thromboses at atypical locations, for example, a Budd-Chiari syndrome should be performed in a specialized center, if possible. It includes local or systemic lysis therapy, and initiation of eculizumab therapy [42]. 
- Primary prophylactic anticoagulation should be considered in patients in whom therapy with eculizumab is not applied [43]. PNH clone size (granulocyte clone $>50 \%$ ) and other thrombophilic risk factors must be taken into consideration.

- Both coumarins and heparins can be applied for therapy and prophylaxis.

\subsubsection{Immunosuppressive Therapy}

- Immunosuppressive therapy as sole treatment of hemolysis activity is not indicated, see Onkopedia Guideline Aplastic Anemia. Eculizumab therapy should be discontinued before therapy with ATG is started, as there will usually be no indication in aplasia (none or only few GPI-deficient erythrocytes) and the efficacy of ATG might be limited (complement-mediated cell lysis).

\subsubsection{Complement Inhibition with Eculizumab}

A new therapeutic strategy consists in the inhibition of the terminal complement system. The humanized monoclonal antibody eculizumab (Soliris ${ }^{\circledR}$ ) binds to complement factor $\mathrm{C} 5$, prevents its cleavage into the fragments $\mathrm{C} 5 \mathrm{a}$ and $\mathrm{C} 5 \mathrm{~b}$, and thus blocks the subsequent formation of the terminal complement complex C5b-9. Therapy is started two weeks after a protective immunization against meningococci. It consists in the administration of $600 \mathrm{mg}$ eculizumab weekly for four weeks, followed by $900 \mathrm{mg}$ eculizumab every two weeks over approx. 30 minutes plus a 60 -minute observational follow-up [41, 44-47].

\section{Indications:}

Eculizumab is intended for use in the treatment of symptomatic patients with paroxysmal nocturnal hemoglobinuria. The drug should be administered particularly in case of complications such as transfusion-requiring anemia (in which case hemolysis-induced and cytopenia-induced anemias should be distinguished [48]), subsequent to previous thromboembolic events, $\mathrm{PNH}$-associated renal failure, crises of abdominal pain, or other serious PNH-related symptoms $[41,49]$. Therapy with eculizumab usually is a long-term treatment, as the underlying cellular defect, relative to the clone size, is not influenced by the administration of the antibody $[46,49]$. Patients previously symptomatic (see above) can benefit from a long-term therapy with eculizumab as it reduces the symptoms and complications associated with the disease, while survival has also been significantly improved as compared to that of a historical control group treated at the same therapy center [49]. 


\section{Risks and Problems:}

- There is an increased risk for infections with capsule-producing bacteria, in particular meningococci, resulting from the inhibition of the terminal complement reaction sequence. Accordingly, protective immunization against meningococci with a tetravalent conjugate vaccine is mandatory at least two weeks prior to onset of therapy (to be repeated every three years; CAVE: There is a high prevalence of the B strains in Europe which have hitherto not been covered by the vaccination).

- In case of symptoms of meningococcal infection (e.g. headaches, accompanied by nausea or vomiting, fever, neck stiffness, skin rash, states of mental confusion) immediate medical diagnostics are required in an emergency plan (emergency ID card!). In addition, a stand-by prophylaxis with $750 \mathrm{mg}$ ciprofloxacin will be reasonable in case there are signs of a meningococcal infection (sudden fever, vigilance disorders, cardiovascular insufficiency, etc.).

- Complete blood cell count, reticulocytes, hemolysis parameters (particularly LDH), iron parameters (particularly ferritin), PNH clone size, folic acid, vitamin $B_{12}$ should be checked on a regular basis under therapy with eculizumab, along with a monospecific Coombs test to determine the existence of complement factors on the surface of erythrocytes (C3d, and, if possible, also C3c) as an indication of extravascular hemolysis [50, 51, 52].

- If there are signs of breakthrough hemolyses an adjustment of the eculizumab dose should be considered under certain circumstances, by shortening the time interval to 12 days [53]. Alternatively, increasing the dose to $1,200 \mathrm{mg}$ eculizumab every $14 \pm 2$ days may be attempted.

- Elective surgical procedures should be scheduled directly after the last administration of eculizumab. In case of potential breakthrough hemolyses an additional dose administration of eculizumab should be taken into consideration. Irrespective of this circumstance perioperative thrombosis prophylaxis should be applied, e.g. with a low-molecular-weight heparin.

- In the event of discontinuation of eculizumab therapy the differential blood cell count and hemolysis parameters should be monitored frequently in order to prevent the occurrence of a serious hemolysis or hemolysis-associated complications [53].

\subsubsection{Pregnancy}

Pregnancies of female PNH patients are associated with a high rate of maternal and fetal lethality (11.6\% and $7.2 \%$, respectively [54]) and each pregnancy is of high risk. Case reports mentioned successful pregnancies under eculizumab without signs of teratogenicity, however, the number of cases was rather low [55]. An ongoing therapy with eculizumab should not be discontinued when pregnancy is diagnosed. If PNH patients have the desire to become pregnant eculizumab therapy should be considered individually after weighing all the risks and complications. Under certain circumstances a dose adjustment will be necessary because 
of the occurrence of breakthrough hemolyses during pregnancy (e.g. maintenance therapy with $900 \mathrm{mg}$ per week).

\subsection{Potential Curative Therapy}

\subsubsection{Allogeneic Stem-Cell Transplantation}

Indications:

An indication for allogeneic stem-cell transplantation in case of PNH ensues in cases of severe aplastic anemia, see Onkopedia Guideline Aplastic Anemia.

Complications like secondary bone marrow due to severe aplastic anemia, MDS, or transition to an acute leukemia, as well as recurrent thromboembolic complications despite thrombosis prophylaxis or eculizumab therapy might present potential situations from which an indication for allogenic stem-cell therapy might ensue.

Problem:

Considerable transplantation-associated morbidity and mortality due to high rates of transplant rejections particularly after conventional conditioning, complications due to infection, and GVHD (long-term survival rates: approx. 50\%-60\%) [56, 57]

\section{References}

1. Strübing P: Paroxysmale Haemoglobinurie. Dtsch Med. Wochenschr 8:1-17, 1882.

2. Ham T: Chronic hemolytic anemia with paroxysmal nocturnal haemoglobinuria. A study of the mechanism of hemolysis in relation to acid-base equilibrium. N Engl J Med 217:915-917,1937.

3. Pillemer L, Blum L, Lepow IH et al.: The properdin system and immunity. I. Demonstration and isolation of a new serum protein, properdin, and its role in immune phenomena. Science 120:279-285, 1954.

4. Nicholson-Weller A, Spicer DB, Austen KF. Deficiency of the complement regulatory protein, "decay-accelerating factor," on membranes of granulocytes, monocytes, and platelets in paroxysmal nocturnal hemoglobinuria. $\mathrm{N}$ Engl J Med 312:1091-1097, 1985. PMID: 3845321

5. Armstrong C, Schubert J, Ueda E, Knez JJ, Gelperin D, Hirose S, Silber R, Hollan S, Schmidt RE, Medof ME. Affected paroxysmal nocturnal hemoglobinuria $\mathrm{T}$ lymphocytes harbor a common defect in assembly of $\mathrm{N}$-acetyl-Dglucosamine inositol phospholipid corresponding to that in class A Thy-1murine lymphoma mutants. J Biol Chem 267:25347-25351, 1992. PMID: 1460030

6. Takeda J, Miyata T, Kawagoe K, lida Y, Endo Y, Fujita T, Takahashi M, Kitani T, Kinoshita T. Deficiency of the GPI anchor caused by a somatic mutation 
of the PIG-A gene in paroxysmal nocturnal hemoglobinuria. Cell 73:703-711, 1993. PMID: 8500164

7. Späth-Schwalbe E, Schrezenmeier H, Heimpel SH. [Paroxysmal nocturnal hemoglobinuria. Clinical experiences with 40 patients at one center over 25 years]. Dtsch Med Wochenschr 120:1027-1033, 1995. PMID: 7628314

8. Oni SB, Osunkoya BO, Luzzatto L. Paroxysmal nocturnal hemoglobinuria: evidence for monoclonal origin of abnormal red cells. Blood 36:145-152, 1970. PMID: 5448520

9. Terstappen LW, Nguyen M, Huang S, Lazarus HM, Medof ME. Defective and normal haematopoietic stem cells in paroxysmal nocturnal haemoglobinuria. Br J Haematol 84:504-514, 1993. PMID: 7693931

10. Karadimitris A, Luzzatto L. The cellular pathogenesis of paroxysmal nocturnal haemoglobinuria. Leukemia 15:1148-1152, 2001. PMID: 11480554

11. Meri S, Morgan BP, Davies A, Daniels RH, Olavesen MG, Waldmann H, Lachmann PJ. Human protectin (CD59), an 18,000-20,000 MW complement lysis restricting factor, inhibits $\mathrm{C} 5 \mathrm{~b}-8$ catalysed insertion of $\mathrm{C} 9$ into lipid bilayers. Immunology 71:1-9, 1990. PMID: 1698710

12. Yamashina M, Ueda E, Kinoshita T, Takami T, Ojima A, Ono H, Tanaka H, Kondo N, Orii T, Okada N, . Inherited complete deficiency of 20-kilodalton homologous restriction factor (CD59) as a cause of paroxysmal nocturnal hemoglobinuria. N Engl J Med 323:1184-1189, 1990. PMID: 1699124

13. Hillmen $P$, Lewis $S M$, Bessler M, Luzzatto L, Dacie JV. Natural history of paroxysmal nocturnal hemoglobinuria. N Engl J Med 333:1253-1258, 1995. PMID: 7566002

14. Socie G, Mary JY, de Gramont A, Rio B, Leporrier M, Rose C, Heudier P, Rochant H, Cahn JY, Gluckman E. Paroxysmal nocturnal haemoglobinuria: long-term follow-up and prognostic factors. French Society of Haematology. Lancet 348:573-577, 1996. PMID: 8774569

15. Valla D, Dhumeaux D, Babany G, Hillon P, Rueff B, Rochant H, Benhamou JP. Hepatic vein thrombosis in paroxysmal nocturnal hemoglobinuria. A spectrum from asymptomatic occlusion of hepatic venules to fatal BuddChiari syndrome. Gastroenterology 93:569-575, 1987. PMID: 3609666

16. Mathieu D, Rahmouni A, Villeneuve P, Anglade MC, Rochant H, Vasile N. Impact of magnetic resonance imaging on the diagnosis of abdominal complications of paroxysmal nocturnal hemoglobinuria. Blood 85:3283-3288, 1995. PMID: 7756661

17. Hoekstra J, Leebeek FW, Plessier A, Raffa S, Darwish MS, Heller J, Hadengue A, Chagneau C, Elias E, Primignani M, Garcia-Pagan JC, Valla DC, Janssen HL. Paroxysmal nocturnal hemoglobinuria in Budd-Chiari syndrome: findings from a cohort study. J Hepatol 51:696-706, 2009. DOI: 10.1016/j.jhep. 2009.06.019

18. Lee JW, Jang JH, Lee JH et al.: High prevalence and mortality of thromboembolism in asian patients with paroxysmal nocturnal hemoglobinuria (PNH). Haematologica 95 Suppl 2: Abstract 505, 2011. 
19. Tichelli A, Gratwohl A, Nissen C, Speck B. Late clonal complications in severe aplastic anemia. Leuk Lymphoma 12:167-175. 1994. PMID: 8167549

20. Frickhofen $\mathrm{N}$, Heimpel $\mathrm{H}$, Kaltwasser JP, Schrezenmeier $\mathrm{H}$. Antithymocyte globulin with or without cyclosporin A: 11-year follow-up of a randomized trial comparing treatments of aplastic anemia. Blood 101:1236-1242, 2003. DOI: 10.1182/blood-2002-04-1134

21. Mukhina GL, Buckley JT, Barber JP, Jones RJ, Brodsky RA. Multilineage glycosylphosphatidylinositol anchor-deficient haematopoiesis in untreated aplastic anaemia. $\mathrm{Br} J$ Haematol 115:476-482, 2001. DOI: 10.1046/j. 1365-2141.2001.03127.x

22. Socie G, Rosenfeld S, Frickhofen N, Gluckman E, Tichelli A. Late clonal diseases of treated aplastic anemia. Semin Hematol 37:91-101, 2000. PMID: 10676914

23. Araten DJ, Swirsky D, Karadimitris A, Notaro R, Nafa K, Bessler M, Thaler HT, Castro-Malaspina $\mathrm{H}$, Childs $\mathrm{BH}$, Boulad $\mathrm{F}$, Weiss M, Anagnostopoulos N, Kutlar A, Savage DG, Maziarz RT, Jhanwar S, Luzzatto L. Cytogenetic and morphological abnormalities in paroxysmal nocturnal haemoglobinuria. $\mathrm{Br} J$ Haematol 115:360-368, 2001. DOI: 10.1046/j.1365-2141.2001.03113.x

24. Hillmen $P$, Elebute $M$, Kelly $R$, Urbano-Ispizua A, Hill A, Rother RP, Khursigara $G$, Fu CL, Omine $M$, Browne $P$, Rosse W. Long-term effect of the complement inhibitor eculizumab on kidney function in patients with paroxysmal nocturnal hemoglobinuria. Am J Hematol 85:553-559, 2010. DOI: 10.1002/ajh.21757

25. Clark DA, Butler SA, Braren V, Hartmann RC, Jenkins DE, Jr. The kidneys in paroxysmal nocturnal hemoglobinuria. Blood 57:83-89, 1981. PMID: 7448417

26. Hill A, Rother RP, Wang X, Morris SM, Jr., Quinn-Senger K, Kelly R, Richards SJ, Bessler M, Bell L, Hillmen P, Gladwin MT. Effect of eculizumab on haemolysis-associated nitric oxide depletion, dyspnoea, and measures of pulmonary hypertension in patients with paroxysmal nocturnal haemoglobinuria. $\mathrm{Br} J$ Haematol 149:414-425, 2010. DOI: 10.1111/j. 1365-2141.2010.08096.x

27. Schrezenmeier $\mathrm{H}$, Höchsmann B. The management of paroxysmal nocturnal hemoglobinuria - recent advances in diagnosis and treatment, and new hope for patients. European Hematology 1:12-18, 2009. http:// www.touchbriefings.com/ebooks/Alfdpu/euhaemavol3issl/resources/ 14.htm

28. Parker C, Omine M, Richards S, Nishimura J, Bessler M, Ware R, Hillmen P, Luzzatto L, Young N, Kinoshita T, Rosse W, Socie G. Diagnosis and management of paroxysmal nocturnal hemoglobinuria. Blood 106:3699-3709, 2005. DOI: 10. 1182/blood-2005-04-1717

29. Borowitz MJ, Craig FE, Digiuseppe JA, Illingworth AJ, Rosse W, Sutherland DR, Wittwer CT, Richards SJ. Guidelines for the diagnosis and monitoring of 
paroxysmal nocturnal hemoglobinuria and related disorders by flow cytometry. Cytometry B Clin Cytom 78:211-230, 2010. DOI: 10.1002/cyto.b.20525

30. Krawitz PM, Schweiger MR, Rodelsperger C, Marcelis C, Kolsch U, Meisel C, Stephani F, Kinoshita T, Murakami Y, Bauer S, Isau M, Fischer A, Dahl A, Kerick M, Hecht J, Kohler S, Jager M, Grunhagen J, de Condor BJ, Doelken S, Brunner HG, Meinecke P, Passarge E, Thompson MD, Cole DE, Horn D, Roscioli T, Mundlos S, Robinson PN. Identity-by-descent filtering of exome sequence data identifies PIGV mutations in hyperphosphatasia mental retardation syndrome. Nat Genet 42:827-829, 2010. DOI: 10.1038/ng.653

31. Almeida AM, Murakami Y, Layton DM, Hillmen P, Sellick GS, Maeda Y, Richards S, Patterson S, Kotsianidis I, Mollica L, Crawford DH, Baker A, Ferguson M, Roberts I, Houlston R, Kinoshita T, Karadimitris A. Hypomorphic promoter mutation in PIGM causes inherited glycosylphosphatidylinositol deficiency. Nat Med 12:846-851, 2006. DOI: 10.1038/nm1410

32. Höchsmann B, Dohna-Schwake C, Rojewski M, Schwarz K, Pannicke U, Schara $U$, Wieland $\mathrm{R}$, Schrezenmeier $\mathrm{H}$. Isolated CD59 deficiency mimicking PNH - flow cytometric detections and genetic characterization. Onkol 33(Abstract, Suppl. 6):112, 2010. DOI: 10.1159/000321410

33. Nebe T, Schubert J, Schrezenmeier H. Flow cytometric analysis of GPI-deficient cells for the diagnosis of paroxysmal nocturnal hemoglobinuria (PNH). J Lab Med. 27:257-265, 2003. DOI: 10.1015/LabMed.2003.038

34. Höchsmann B, Rojewski M, Schrezenmeier H. Paroxysmal nocturnal hemoglobinuria (PNH): higher sensitivity and validity in diagnosis and serial monitoring by flow cytometric analysis of reticulocytes. Ann Hematol. Epub Feb 26, 2011; DOI: 10.1007/s00277-011-1177-4

35. Richards SJ, Rawstron AC, Hillmen P. Application of flow cytometry to the diagnosis of paroxysmal nocturnal hemoglobinuria. Cytometry 42:223-233, 2000. DOI: 10.1002/1097-0320(20000815)

36. Brecher ME, Taswell HF. Paroxysmal nocturnal hemoglobinuria and the transfusion of washed red cells. A myth revisited. Transfusion 29:681-685, 1989. DOI: 10.1046/j.1537-2995.1989.29890020439.x

37. Röth A, Schubert J, Hock Ch, Christoph S, Dührsen U. Effect of reducing intravascular hemolysis on ferritin homeostasis in eculizumab treated paroxysmal nocturnal hemoglobinuria (PNH) patients. Blood 112:3437, 2008.

38. Issaragrisil S, Piankijagum A, Tang-naitrisorana Y. Corticosteroids therapy in paroxysmal nocturnal hemoglobinuria. Am J Hematol 25:77-83, 1987. DOI: 10.1002/ajh.2830250108

39. Bourantas K. High-dose recombinant human erythropoietin and low-dose corticosteroids for treatment of anemia in paroxysmal nocturnal hemoglobinuria. Acta Haematol 91:62-65, 1994. DOI: 10.1159/000204254

40. Zhao M, Shao Z, Li K, Chen G, Liu H, Zhang Y, He H, Shi J, He G, Chu Y, Yang T. Clinical analysis of 78 cases of paroxysmal nocturnal hemoglobinuria 
diagnosed in the past ten years. Chin Med J (Engl) 115:398-401, 2002. PMID: 11940374

41. Hillmen $P$, Muus $P$, Dührsen $U$, Risitano $A M$, Schubert J, Luzzatto $L$, Schrezenmeier H, Szer J, Brodsky RA, Hill A, Socie G, Bessler M, Rollins SA, Bell L, Rother RP, Young NS. Effect of the complement inhibitor eculizumab on thromboembolism in patients with paroxysmal nocturnal hemoglobinuria. Blood. 2007;110:4123-4128, 2007. DOI: 10.1182/ blood-2007-06-095646

42. McMullin MF, Hillmen P, Jackson J, Ganly P, Luzzatto L. Tissue plasminogen activator for hepatic vein thrombosis in paroxysmal nocturnal haemoglobinuria. J Intern Med 235:85-89, 1994. DOI: 10.1111/j. 1365-2796.1994.tb01037.x

43. Hall C, Richards S, Hillmen P. Primary prophylaxis with warfarin prevents thrombosis in paroxysmal nocturnal hemoglobinuria (PNH). Blood 102:3587-3591, 2003. DOI: 10.1182/blood-2003-01-0009

44. Hillmen P, Hall C, Marsh JC, Elebute M, Bombara MP, Petro BE, Cullen MJ, Richards SJ, Rollins SA, Mojcik CF, Rother RP. Effect of eculizumab on hemolysis and transfusion requirements in patients with paroxysmal nocturnal hemoglobinuria. N Engl J Med 350:552-559, 2004. PMID: 14762182

45. Hillmen P, Young NS, Schubert J, Brodsky RA, Socie G, Muus P, Röth A, Szer J, Elebute MO, Nakamura R, Browne P, Risitano AM, Hill A, Schrezenmeier $H$, Fu CL, Maciejewski J, Rollins SA, Mojcik CF, Rother RP, Luzzatto L. The complement inhibitor eculizumab in paroxysmal nocturnal hemoglobinuria. N Engl J Med 355:1233-1243, 2006. PMID: 16990386

46. Brodsky RA, Young NS, Antonioli E, Risitano AM, Schrezenmeier H, Schubert J, Gaya A, Coyle L, de Castro C, Fu CL, Maciejewski JP, Bessler M, Kroon HA, Rother RP, Hillmen P. Multicenter phase 3 study of the complement inhibitor eculizumab for the treatment of patients with paroxysmal nocturnal hemoglobinuria. Blood 111:1840-1847, 2008. DOI: 10.1182/ blood-2007-06-094136

47. Röth $A$, Dührsen $U$, Schrezenmeier $H$, Schubert J. Paroxysmal nocturnal hemoglobinuria (PNH). Dtsch Med Wochenschr 134:404-409, 2009. DOI: 10.1055/s-0028-1124013

48. Röth A, Dührsen U. Treatment of paroxysmal nocturnal hemoglobinuria in the era of eculizumab. Eur J Haematol. 2011 Dec;87(6):473-9. DOI: 10.1111/j.1600-0609.2011.01701.x

49. Kelly RJ, Hill A, Arnold LM, Brooksbank GL, Richards SJ, Cullen M, Mitchell LD, Cohen DR, Gregory WM, Hillmen P. Long-term treatment with eculizumab in paroxysmal nocturnal hemoglobinuria: sustained efficacy and improved survival. Blood 117:6786-6792, 2011. PMID:21460245

50. Röth A, Hock C, Konik A, Christoph S, Dührsen U. Chronic treatment of paroxysmal nocturnal hemoglobinuria patients with eculizumab: safety, effi- 
cacy, and unexpected laboratory phenomena. Int J Hematol 93:704-14, 2011. DOI:10.1007/s12185-011-0867-y

51. Risitano AM, Notaro R, Marando L, Serio B, Ranaldi D, Seneca E, Ricci P, Alfinito F, Camera A, Gianfaldoni G, Amendola A, Boschetti C, Di Bona E, Fratellanza G, Barbano F, Rodeghiero F, Zanella A, lori AP, Selleri C, Luzzatto L, Rotoli B. Complement fraction 3 binding on erythrocytes as additional mechanism of disease in paroxysmal nocturnal hemoglobinuria patients treated by eculizumab. Blood 113:4094-4100, 2009. DOI: 10.1182/ blood-2008-11-189944

52. Röth A, Peine S, Dührsen U. Paroxysmal nocturnal hemoglobinuria turning Coombs-positive. Int J Hematol 91:159-160, 2010. DOI: 10.1007/ s12185-010-0493-0

53. Fachinformation Soliris ${ }^{\circledR}$. 2009.

54. Fieni S, Bonfanti L, Gramellini D, Benassi L, Delsignore R. Clinical management of paroxysmal nocturnal hemoglobinuria in pregnancy: a case report and updated review. Obstet Gynecol Surv 61:593-601, 2006. PMID: 16919177

55. Kelly R, Arnold L, Richards S, Hill A, Bomken C, Hanley J, Loughney A, Beauchamp J, Khursigara G, Rother RP, Chalmers E, Fyfe A, Fitzsimons E, Nakamura R, Gaya A, Risitano AM, Schubert J, Norfolk D, Simpson N, Hillmen $\mathrm{P}$. The management of pregnancy in paroxysmal nocturnal haemoglobinuria on long term eculizumab. Br J Haematol 149:446-450, 2010. DOI: 10.1111/j.1365-2141.2010.08099.x

56. Saso R, Marsh J, Cevreska L, Szer J, Gale RP, Rowlings PA, Passweg JR, Nugent ML, Luzzatto L, Horowitz MM, Gordon-Smith EC. Bone marrow transplants for paroxysmal nocturnal haemoglobinuria. $\mathrm{Br} J$ Haematol 104:392-396, 1999. DOI: 10.1046/j.1365-2141.1999.01195.x

57. Matos-Fernandez NA, Abou Mourad YR, Caceres W, Kharfan-Dabaja MA. Current status of allogeneic hematopoietic stem cell transplantation for paroxysmal nocturnal hemoglobinuria. Biol Blood Marrow Transplant 15:656-661, 2009. DOI: 10.1016/j.bbmt.2008.12.507

\section{Links}

Interlaboratory ring trials: http://www.instandev.de/ringversuche/

\section{Authors' Affiliations}

Prof. Dr. med. Jörg Schubert

Elblandklinikum Riesa

Weinbergstr. 8

01589 Riesa

Tel: 03525755756

joerg.schubert@elblandkliniken.de 


\section{Prof. Dr. Peter Bettelheim}

Krankenhaus der Elisabethinen Linz

Abteilung für Hämatologie,

internistische Onkologie und Stammzelltransplantation

Fadingerstr. 1

A-4020 Linz

Tel: 0043732 7676-0

peter@bettelheim.eu

Univ.-Prof. Dr. med. Tim Henrik Brümmendorf

Universitätsklinikum Aachen

Medizinische Klinik IV

Hämatologie und Onkologie

Pauwelsstr. 30

52074 Aachen

Tel: $024180-89805$

Fax: $024180-82449$

tbruemmendorf@ukaachen.de

PD Dr. med. Alexander Röth

Universitätsklinikum Essen

Klinik für Hämatologie

Westdeutsches Tumorzentrum

Hufelandstr. 55

45122 Essen

Tel: $0201723-84219$

Fax: $0201723-1716$

alexander.roeth@uk-essen.de

Prof. Dr. med. Hubert Schrezenmeier

Universitätsklinikum UIm

Institut f. klin. Transfusionsmedizin

Helmholtzstr. 10

$89081 \mathrm{UIm}$

Tel: 0731 150-550

Fax: 0731 150-500

h.schrezenmeier@blutspende.de

PD Dr. med. Georg Stüssi

Servizio di Ematologia

Istituto oncologico della

Svizzera Italiana

Viale Ospedale

CH-6500 Bellinzona

Tel: 0041918118778

georg.stuessi@eoc.ch 


\section{Disclosures}

According to the rules of the DGHO (German Association of Hematology and Oncology), the recommendations of the AWMF (Version as by April 23, 2010) and international recommendations:

\begin{tabular}{|c|c|c|c|c|c|c|c|}
\hline Name & $\begin{array}{l}\text { Employ- } \\
\text { ment / Exec- } \\
\text { utive Posi- } \\
\text { tion }\end{array}$ & $\begin{array}{c}\text { Counsel- } \\
\text { ing / } \\
\text { Expert } \\
\text { Reports }\end{array}$ & $\begin{array}{l}\text { Shares/ } \\
\text { Funds }\end{array}$ & $\begin{array}{l}\text { Patent / } \\
\text { Copy- } \\
\text { right/ } \\
\text { License }\end{array}$ & $\begin{array}{c}\text { Royal- } \\
\text { ties }\end{array}$ & $\begin{array}{l}\text { Financing of } \\
\text { Scientific } \\
\text { Research }\end{array}$ & $\begin{array}{c}\text { Other } \\
\text { Finan- } \\
\text { cial } \\
\text { Rela- } \\
\text { tions }\end{array}$ \\
\hline $\begin{array}{l}\text { Bettel- } \\
\text { heim }\end{array}$ & $\begin{array}{l}\text { General } \\
\text { Hospital of } \\
\text { the Elisa- } \\
\text { bethinen, } \\
\text { Linz }\end{array}$ & - & - & - & $\begin{array}{l}\text { Alex- } \\
\text { ion }\end{array}$ & - & - \\
\hline $\begin{array}{l}\text { Brümmen- } \\
\text { dorf }\end{array}$ & $\begin{array}{c}\text { University } \\
\text { Hospital of } \\
\text { Aachen }\end{array}$ & - & - & - & $\begin{array}{l}\text { Alex- } \\
\text { ion }\end{array}$ & - & - \\
\hline Röth & $\begin{array}{c}\text { University } \\
\text { Hospital of } \\
\text { Essen }\end{array}$ & Alexion & - & - & $\begin{array}{l}\text { Alex- } \\
\text { ion }\end{array}$ & Alexion & - \\
\hline $\begin{array}{l}\text { Schrezen- } \\
\text { meier }\end{array}$ & $\begin{array}{c}\text { University } \\
\text { Hospital of } \\
\text { Ulm }\end{array}$ & Alexion & - & - & $\begin{array}{l}\text { Alex- } \\
\text { ion, } \\
\text { Gen- } \\
\text { zyme }\end{array}$ & $\begin{array}{l}\text { Alexion, } \\
\text { Genzyme }\end{array}$ & - \\
\hline Schubert & $\begin{array}{c}\text { Evangelical } \\
\text { Hospital of } \\
\text { Hamm }\end{array}$ & Alexion & & & & & \\
\hline Stüssi & $\begin{array}{c}\text { Istituto } \\
\text { oncologico } \\
\text { della } \\
\text { Svizzera } \\
\text { Italiana }\end{array}$ & Alexion & - & - & $\begin{array}{l}\text { Alex- } \\
\text { ion }\end{array}$ & - & - \\
\hline
\end{tabular}

